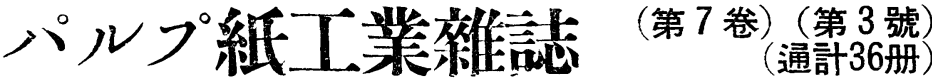

俔利 28 年 6 月 20 日

\section{リグニン及びパルプに關する研究}

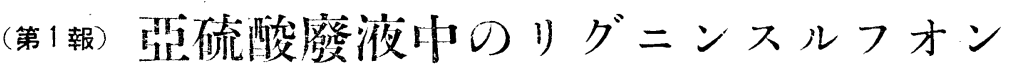

酸の新定显法（コロイド滴定）

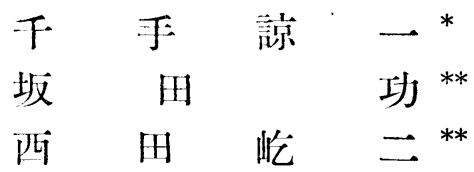

\section{（I）緒言}

廢液中のリグニン・スルフォン酸（以下L.S. と略記する）の定量法汇関して，掏袁されてい る方法は，a）随堂なる沈澱劑汇上つてL.Sを 沈洪せしめ，之を瀘過，乾燥，科量するか，或

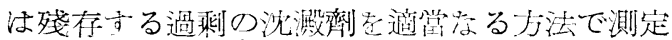
して求的る值接法之， b) 蔡液中心冞固形物中

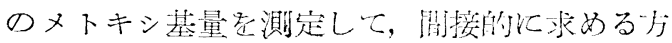
法とである。

從來力ら割合廣く使用されている沈澱劑とし ては，ß-ナフチルアミンで Partansky1: 法が

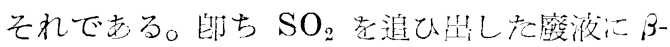

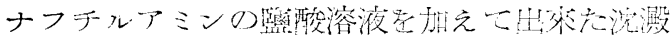

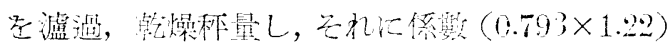

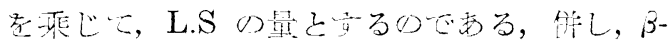

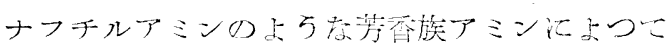

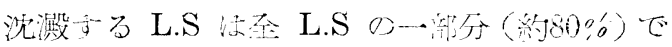
あつて是量的で尔い。 久 L.S とアミンの含

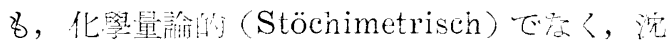

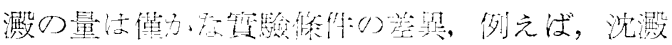

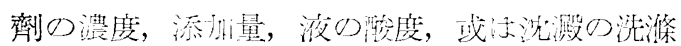

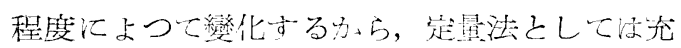

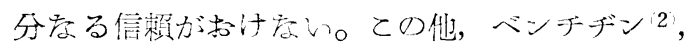
下リパフラビン 3 ，抽リン4， ベンツアクリ ヂン 5 ，ブルシン 6 ，ヂメチルアミノ・デフ ニールアミン6，フクシン7等が登表されてい

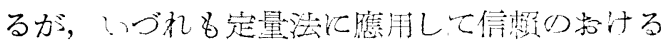
ものが存い。

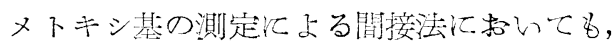
蒸解の涂中キシ基の脫離が無い場含にの み正しい。久L.S 亿就いては，其の精鳌度に上

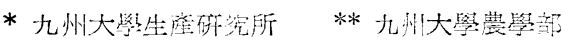

つて係敖を變化せ权ばならぬ。從つていづれの

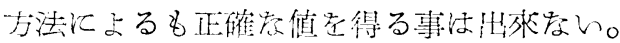

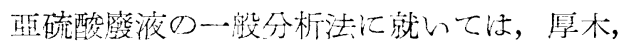
友田，紫月\&， Partansky and Berson'1), Schwalbe-Sieber ${ }^{9}$ ，摆逸公定法 ${ }^{10}$ ，及び内 田11，の䃄究化よつて，一應體系づけられてい る化も拘ら市，庣液の主成尔であるL.Sの定量 法汇關して法，未だ漂準化されたものがをく， 嘪逸公定法汇沶いても之学除外している现狀で

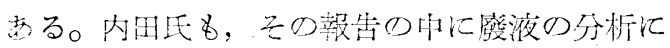

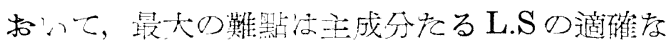
是鼠法が李い萦であると嗼じている。

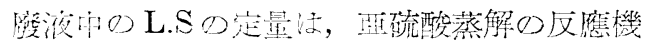

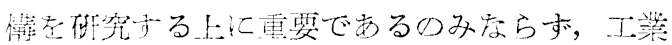

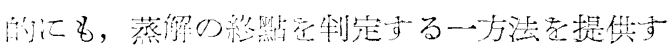

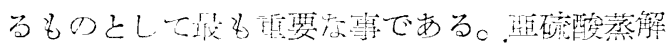

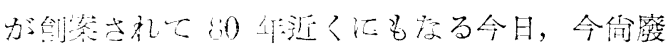

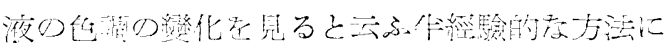

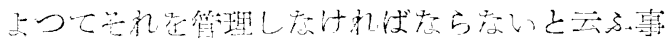

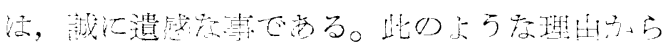

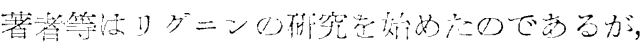

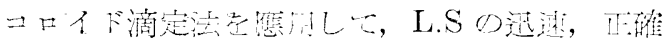

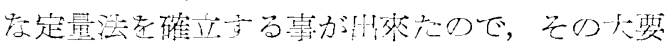
老報击与る。

\section{（II）滴定法の原理}

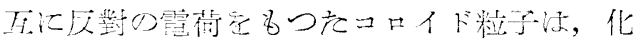

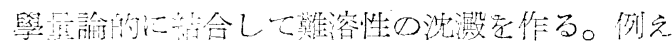

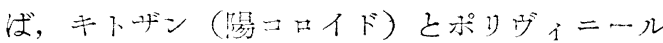

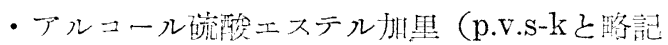

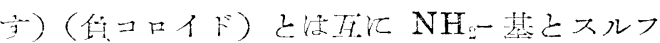

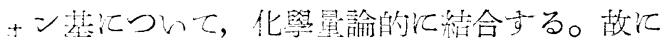
負コロイドに一定奄のキトザン恕加之，消費さ 
れ無かつたキトザンを別の負コロイド(p.v.s-k) で逆滴定すれば，負コロイドによつて消費され たキトザンの量が求められる。此の滴定の終點 の判定には，“メタクロマジー”を呈する色素, 例えば，トルイヂン・ブラウ等を使用する。此 の色素は，陽コロイド(キトザン）には吸着さ れす，本來の靑色であるが，負コロイド（p.v. $\mathrm{s}-\mathrm{k}$ 等）飞は優先的に吸着されて赤紫色沙戀色 する。故に，ての變色點をもつて滴定の終點と するのである。

L.S タ一種の售コロイドであるから，陽コロ イド例えばキトザンで沈澱する䉪である。 L.S やタンニンがゼラチンで沈澱するのもとの原理 である。此の反對電荷の高分子電解筫が相互に 難溶性の沈搌考作る事注，高分子電解質の特性 と思われる。其の相互の結合力は，當分子をる が故に倍加された酹電氣のクーロン引打ある。 故江高分子電解質の解離基の解離度之其の分子 重合度の大きい程，相互の沈澱壮完全であり，

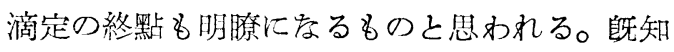
の如く廢液中には高分子の L.S $(\alpha-$ L.S $)$ の他汇 向か孝りの量の低分子の L.S ( $\beta$-L.S) が存在す る。故注液中の L.S \& $\beta$-L.S までも完至に 沈澱せしめる爲には，沈澱劑としてのアミン化 合物法出來る文重合度の大きいものを使用する

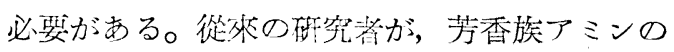

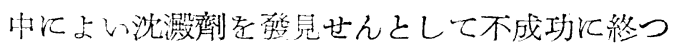

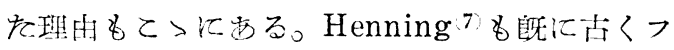
クシンとよるコロイド滴定を登表しているが, その滴定終點が不明膫で沈洪量も是量的でない 理由タフクシンの低分子性に基せられる。此の よう存考えから著者等はか权て浙究してい老グ リコールキトザン（以下 G.Ch と略郎す）（重 合度約600）老其の沈潵劑使朋してL.S のコ ロイド滴定学可能ならしめ志。

\section{（II）試藥の調製}

a) p.v-s-k の合成

ポリヴィニール・アルコールをピりヂンの存 在下に沶いてクロール・スルフォン酸で硫酸化 した。製品の硫黄含量浪， $19.26 \%$ \%あつたか ら，97.5\%がエステル化されている事に存る。 p.v.s-k は次の樣存式で示される。

$$
\left(\begin{array}{r}
-\mathrm{CH}_{2}-\mathrm{CH}- \\
\mathrm{SO}_{3} \mathrm{~K}
\end{array}\right)_{\mathrm{n}}
$$

從つて，スルフォン基當りの虽量分子量は, 146 になる。滴定にはその n/400の液を使用する。

b) G. Ch の調製

キチンをグリコール化しを後, 脫アセチル化 して製造した。粘度測定による分子重合度は約 600 である。

製品の分析結果は次の如くである。

Gef. Ber

$\left(\mathrm{C}_{8} \mathrm{H}_{14} \mathrm{O}_{5}=\mathrm{NH}_{2}=206\right)$

N- Gehalt (nach Kjeldahl) $6.71 \quad 6.82$

$\mathrm{NH}_{2}$-gehalt (nach Vanshylk) $7.67 \quad 7.70$

$\mathrm{NH}_{2}$-gehalt (nach Kolloidtitration)

$\begin{array}{ll}7.70 & 7.72\end{array}$

$\mathrm{NH}_{2}$ - 基の含量については，三者の方法によ る值が全く一致している。これは脫アセチル化 は完奎であり， p.v.s-k と G.Ch との結合も化 學量諭的である事を示すものである。郎ち $\mathrm{NH}_{2}$ 當りの當量分子量汇 206 と云子事になる。佾 n/100の p.v.s-k 及び G.Ch の 50ce づつか ら得られた沈澱の量は $0.1643 \mathrm{~g}$ であつた。てれ より求めを G. Ch の賞量分子量は 204 である。 兩者の一致は極めて見事である。

併し常にての組成のものが得られると云らわ けではない。グリコール化, 脫アセチル化の程 度によつて $\mathrm{NH}_{2}$ 一基含量は變化する。併しコロ イド滴定には， $\mathrm{NH}_{2}$ 一基含量が分ればよんのだ から，慜品のアミノ基含量をVanslyk-法又は p.v.s-k によるコロイド滴定によつて測定すれ ばそれで充分である。L.S の是量には，著者等 はn/100の液使用している。即ち, 風乾物約 $3.2 \mathrm{~g}$ を $1 l$ 亿と务し醋酸又壮 $\mathrm{HCl}$ で $\mathrm{PH}$ 2〜4 程度にして， $\mathrm{NH}_{2}$ 基を完全に解離せしめ る。著者等は $\mathrm{n} / 10$ の䤃酸酸性にして使用して いる。ての 5cc を取り濃度既知の p.v.s-k で滴 定する。乙の際指示藥として，トルイヂンブラ ウ（メルク製のるのを使用する事）の $0.1 \%$ 水 溶液 1 滴を加えておく。當量點まで注色素の本 來の青色走すが，1滴過剩の p.v.s-k が添加 さるれば色素法 p.v.s-k 江着されて赤紫色に 友る。此の點を終點とする。

（IV）滴定方法 (亞硫酸蒸解の調節管理を對照 として記載する。）

n/100-G.Ch $15 \mathrm{cc}$ を $50 \mathrm{cc}$ の三侍コルベンに

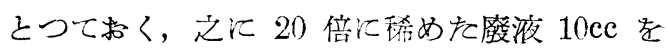
加える。洸澱の一部は G.Ch の强々乳化力によ 
つて牛乳狀に分散する。2〜3 分放置後ジム栓 或は氣密を共栓をして數秒閐强く振盪する。沈 澱は氣泡と共に表面に浮き上り，液相は乳濁し ている。之を p.v.s-k で滴定して行く。L.S と 結合しなかつを G.Ch は添加された p.v.s-k と 結合して沈澱となり，氣泡と其飞袁面飞浮を， 液相の混濁度の制定が容易である。痕跡の G.

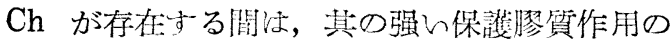
鳳飞液相は乳濁しているが，丁度堂最の p.v.s-k が滴加さるれば突然蓩が睛れるように透明にな

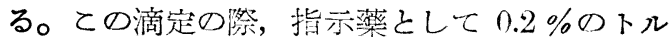
イヂンブラウの 1〜2 滴を加えておけけ憆量點

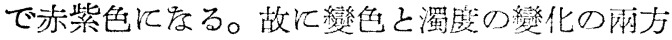
から終點がよく制る。滴定誤差は士0.02ec で ある。

L.S と G.Ch の化合物汸, トルイヂンブラ ウを極めてよく吸着して變色を妨げる。故に指 示藥を使用多る場合飞は出來る岇け滴定終點の 近くで加えるがよん。沘澱に吸着されて液相の 着色が淡くなつを場合汇は，更に 1 2 滴の指

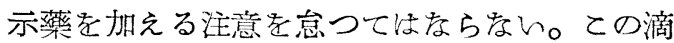
定は指示藥なしでも充分正確汇行ん得る。L.S の濃度が大きん場合には，むしろ指示藥索使用 しない方が便利である。廃液を極度（50１00
倍）に稀籜して指示藥を使用して滴定を行ら方 法もあるが，蒸解㭙間の偉少の差，例えば 10 分の差がよく滴定值に現われるようにする爲に はある程度の量の廢液を取る必要がある。滴定 におんて，G.Ch に L.S の液を加えるように 記䢞し岕がこれは測定のスピード化老考えて行

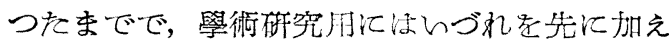
ておいても差支えない。別に使用した G.Chの 白試驗考行つて括けば，本實驗との差から廢液 1cc が消費する G.Ch の ce 數が分る。

\section{（V） L.S の當量分子量}

L.S のポリアミン消費量（以下 P.A.V と 略記する）は加える G.Ch の量には全く無關係 である。てれは，L.S と G.Ch の結合が化學 量論的に行われている登であるが， E.Brauns 氏の私信による注意もあつたので，佾ての事老 確める爲に L.S と G.Ch の沈澱の $\mathrm{S}$ と $\mathrm{N} の$ 含量を測定した絬果，乙の比洼 $1: 1$ で L.S と G. Ch とが全く化學量論的汇結合している事が 明らかとをつた。G.Ch の消費量が焦える G.Ch の量汇無關係であるのもこの為であつて，てれ 注容量分析には極的て重要㾣事である。故江吾 吾は, L.S と G.Ch の沈澱の量から G. Ch の

Tabelle 1. Die Ablauge von Papierzellstoff-Fabrik.

\begin{tabular}{|c|c|c|c|c|c|c|c|c|c|}
\hline \multirow{2}{*}{$\begin{array}{l}\text { Kochzeit } \\
\text { in Min. }\end{array}$} & \multirow{2}{*}{$\begin{array}{l}\text { Ablauge } \\
(\mathrm{ccm})\end{array}$} & \multirow{2}{*}{$\begin{array}{l}\text { Addierte } \\
\mathrm{ccm} \mathrm{n} / 100- \\
\text { G. Ch.-lös. }\end{array}$} & \multicolumn{2}{|c|}{$\begin{array}{l}\text { Verbrauchte } \\
\text { P.V.S-K zur } \\
\text { Zurücktitr. }\end{array}$} & \multicolumn{2}{|c|}{$\begin{array}{l}\text { Verbrauchtes } \\
\text { G.Ch. zur } \\
\text { Fällung }\end{array}$} & \multirow{2}{*}{$\begin{array}{l}\text { Nieder- } \\
\text { schlag } \\
\text { mg/ccm } \\
\text { Ablauge }\end{array}$} & \multirow{2}{*}{$\begin{array}{l}\text { Lignin- } \\
\text { sulfosäure } \\
\text { gehalt. } \\
\text { mg/ccm } \\
\text { Ablauge }\end{array}$} & \multirow{2}{*}{$\begin{array}{l}\text { Aquiva- } \\
\text { lentge- } \\
\text { wicht } \\
\text { der L.S. }\end{array}$} \\
\hline & & & $\operatorname{ccm} n / 400$ & $\mathrm{mg}$ & $\operatorname{ccm} \mathrm{n} / 100$ & $\mathrm{mg}$ & & & \\
\hline 420 & 1 & 22.00 & 11.50 & 9.3 & 19.13 & 39.4 & 121.1 & 72.4 & 379 \\
\hline 450 & 1 & 24.00 & 10.40 & 8.4 & 21.40 & 44.1 & 134.0 & 81.5 & 381 \\
\hline 510 & 1 & 27.00 & 9.35 & 7.5 & 24.66 & 50.8 & 151.5 & 93.2 & 379 \\
\hline 570 & 1 & "I & 7.55 & 6.1 & 25.00 & 51.5 & 155.1 & 97.5 & 390 \\
\hline 600 & 1 & ") & 6.50 & 5.3 & 25.38 & 52.3 & 152.9 & 95.4 & 376 \\
\hline 690 & 1 & "I & 3.80 & 3.1 & 26.05 & 53.7 & 155.3 & 98.6 & 378 \\
\hline
\end{tabular}

Tabelle 2. Die Ablauge von Kunstseidezellstoff-Fabrik

\begin{tabular}{|c|c|c|c|c|c|c|c|c|c|}
\hline Kochzeit & \multirow{2}{*}{$\begin{array}{l}\text { Ablauge } \\
(\mathrm{ccm})\end{array}$} & \multirow{2}{*}{$\begin{array}{l}\text { Addierte } \\
\mathrm{ccm} \mathrm{n} / 100- \\
\text { G. Ch.-lös. }\end{array}$} & \multicolumn{2}{|c|}{$\begin{array}{l}\text { Verbrauchte } \\
\text { P.V.S.-K für } \\
\text { Zurücktitr. }\end{array}$} & \multicolumn{2}{|c|}{$\begin{array}{l}\text { Verbrauchtes } \\
\text { G.Ch. für } \\
\text { Fällung }\end{array}$} & \multirow{2}{*}{$\begin{array}{l}\text { Nieder- } \\
\text { schlags- } \\
\text { menge } \\
\mathrm{mg} / \mathrm{ccm} \\
\text { Ablauge }\end{array}$} & \multirow{2}{*}{$\begin{array}{l}\text { Nieder- } \\
\text { schlag } \\
\text { der L.S. } \\
\text { mg/ccm } \\
\text { Ablauge }\end{array}$} & \multirow{2}{*}{$\begin{array}{l}\text { Aquivalent } \\
\text { gewicht } \\
\text { der L.S. }\end{array}$} \\
\hline in Min. & & & $\mathrm{ccm} \mathrm{n/400}$ & $\mathrm{mg}$ & $\mathrm{ccm} \mathrm{n} / 100$ & $\mathrm{mg}$ & & & \\
\hline 460 & 3 & 23.00 & 11.20 & 9.0 & 20.7 & 42.7 & 132.1 & 80.3 & 388 \\
\hline 520 & 3 & 27.60 & 9.50 & 7.7 & 24.6 & 50.9 & 148.0 & 89.4 & 363 \\
\hline 570 & 2 & 25.00 & 10.00 & 8.1 & 22.5 & 46.4 & 140.0 & 85.5 & 380 \\
\hline 610 & "1 & 26.00 & 5.70 & 4.6 & 24.6 & 50.6 & 147.0 & 92.4 & 377 \\
\hline 640 & " & 30.00 & 9.00 & 7.3 & 27.8 & 57.2 & 168.0 & 105.9 & 383 \\
\hline 660 & "I & 30.00 & 2.80 & 2.3 & 29.3 & 60.4 & 175.3 & 112.6 & 385 \\
\hline
\end{tabular}


虽量分子量（206）を差引いた L.S の量から 1 モルの G.Ch によつて沈澱する L.S の量郎ち $\mathrm{NH}_{2}$ - 基當りの當量分子量が求められる。第 1 - 2 洨の5行目の數がそれである。

第 1 表と 2 表の試料は全く異る工場のもので あるにも拘らず，その堂量分子量は全く同心゙で

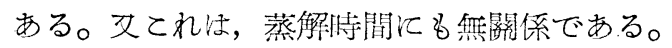
故に廢液の G. Ch の沙費量が分れば直ちに L.S 量が求められる。n/400の $1 \mathrm{cc}$ 注 $0.95 \mathrm{mg} の$ L.S に相賞する。

滴定時の P. $\mathrm{H}$ と P. A. V との關係

コロイド滴定の原理汪, 前述のよろに, 高分 子電解質分子中化ある解離基を定量する方法で あるから，L.S の P.A.V が P. H によつて

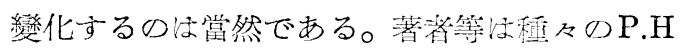
で P.A.V を求めをのであるが，其の結果は 第1 圖の如くである。液の $\mathrm{PH}$ は滴是後直ち とガラ大電極 $\mathrm{PH}$ 部で測定しを。

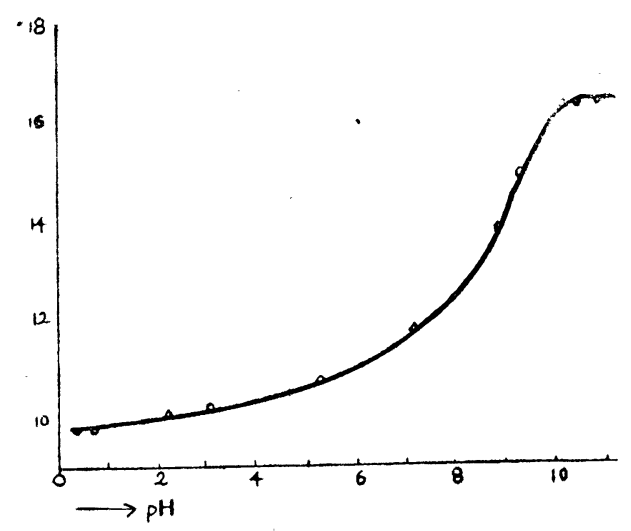

第 1 阔

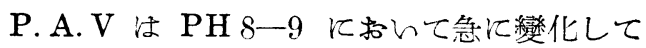
んるが $\mathrm{PH} 2$-5 と $\mathrm{PH} 10.5$ 以上では殆んど 恒値である。故に $\mathrm{PH} 2-4$ で滴定すればよい 再現性をるつて L.S を定量する事が出來る。 工場廢液のよ5に若干の $\mathrm{SO}_{2}$ 告含有するるの は稀程盀值ちに滴定してよいが，さうでをい場 合に注常江 PH 2-4 位にして滴定すべきであ

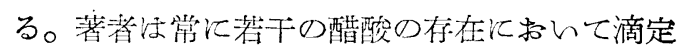
する事にしている。

PH 11 以上の P.A. V が PH 3 のそれの約 1.62 倍である專洁, L. S の當量分子量が 380 で ある事から将えてリグニンの一分子を 840 とす ればスルフォン基が 2.8 個, フェノール性或は エノール性 $\mathrm{OH}$ が 1.7 個平均西る事化存る。

\section{（VI）測定の正確さ}

從來 L.S の沈澱劑として, 最も銃敏を子の

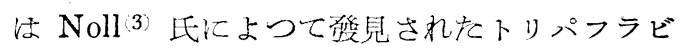
ンであるとされている。故化トリパフラビン反 應と著者の G. Ch の反應の銃敏度を比較した。 其の結果法，第 3 輩の如くである。

トリパフラビンの場合法 10ce : 1000 の稀䆁

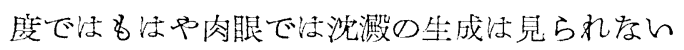
が G. Ch: で洼 1.25: 1000 の稀釋度でさえ, 合 明らか存沈洪の生成が認められる。此の鈗敏度 はまさに 4 ガンマー $(0.000004 \mathrm{~g})$ 以上である。 G. Ch. 汇よる L.S の定量が如何に正確である かがよく分る。

最後に本㸴究逐行に當り種及御援助を賜つた 高千穗製紙の鈴木社長，澤正治工柔部长を始め 研究課の北川謙次氏汇深甚の謝意を萃したん。

Tabelle 3. Empfindlichkeit der Glykol-Chitosan-Reaktion

\begin{tabular}{|c|c|c|c|c|}
\hline \multirow{2}{*}{ Sulfitablauge } & \multirow{2}{*}{$\begin{array}{c}\mathrm{Zu} \mathrm{je} 0.1 \mathrm{ccm} \\
0.1 \text {, irges } \\
\text { Reagens zugesetzt } \\
\text { Tropfen }\end{array}$} & \multirow{2}{*}{$\begin{array}{c}1 \text { Tropfen } \\
\text { enthä!t } \\
\text { Gamma } \\
\text { Ligninsulfosäure }\end{array}$} & \multicolumn{2}{|c|}{ Ausfall der Reaktion } \\
\hline & & & G. ch. & Trypaflavin \\
\hline $10 \mathrm{ccm}: 1000$ & 1 & 32 & starke Fällung & $\begin{array}{l}\text { mit blossem Auge } \\
\text { nicht mehr, mit } \\
\text { der Lupe noch } \\
\text { wahrnehmbare Fällung }\end{array}$ \\
\hline $5 \quad$ ccm $: 1000$ & 1 & 16 & starke Fällung & $\begin{array}{l}\text { nicht mehr } \\
\text { wahrnehmbar }\end{array}$ \\
\hline $2.5 \mathrm{ccm}: 1000$ & 1 & 8 & $\begin{array}{l}\text { schwache } \\
\text { Fällung }\end{array}$ & "l \\
\hline $1.25 \mathrm{ccm}: 1000$ & 1 & 4 & $\begin{array}{l}\text { mit blossem } \\
\text { Auge noch } \\
\text { nehmbare } \\
\text { Fällung }\end{array}$ & $" \prime$ \\
\hline
\end{tabular}


1) A. M. Partansky and H.K. Benson, Paper Trad J. 102. No. 7. 29 (1936)

2) B. Rassow u. H. Kraft, Papier Fabr. 29, 89 (1929)

3) A. No11, ibid. 36. 41 (1938)

4) K. Freudenberg u. F. Sohns, Ber. 66. 262 (1933)

5) V. Lautsch and G. Piazolo, Cellulosechemie 22. $48-54(1944)$

6) H. Erdman, Svensk Paperstidn, 45. 374-80 (1942), C. A. 37. 1864
7) Hennig, Pap. Fabr. 30. 179 (1932)

8) 厚木, 友田, 望月：工化 28981 (1925)

9) C. G. Schwalbe u. R. Sieber : Die chemische Betriebskontrolle in der Zellstoff- und Papier-. Industrie. 3 Aufl. 1931

10) Verein. d. Zellstoff-und Papier-Chemiker und Ingeniur Fachausschuss : Papier Fabr. 35. 283. (1937)

11）內田：工化， $44341-46,1072-75$ (昭16), 45 , 800-6（昭17）

(28. 3. 23. 受付)

\section{リダニン及びパルプに關する研究}

\section{(第2報) 植物體中のリグニンの新定量法（コロイド滴定）}

\section{（I）緒言}

植物能中のリグニンの定量法汇就いたは多種 多样索方法が提案されりいるが，之老大別する

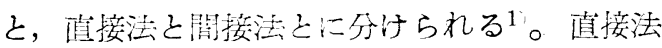

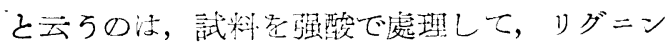
以外の物筫を分解し去り殘渣を“りグニン”之 して重量的汇求める方法である。間接法と云う のは試料中のメトキシ基量或はハロがン，フロ ログルチン，酸化劑の消費量から間接的化，リ グニンを求める方法であるが，測定汇嚴密索條 件を党必要とし，正㴶志值を示さなんので，パル プ中のリグニン先是量する以外汇䋡り利用さ れ孝い。

リグニンの定量に割合廣く，探用されている の法 $72 \%$ 酤酸法” (Klason 法) 之 $42 \%$ 監酸 法3 (Willstätter 法)である。この方法は，制 合道汇近い值與えるとされているが，分析汇 長時閏学要する候點がある。文糖類のフューミ ン化の閏題も殘つている。へミセルローズの多

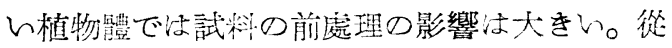

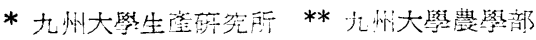

\begin{tabular}{|c|c|c|c|}
\hline 千. & 手 & 誩京 & _. * \\
\hline$\sqrt{13}$ & 水 & 基 & 屾。 \\
\hline & 田 & 峻 & $=$ \\
\hline
\end{tabular}

つてまだ世界共通の標潗法と云うものがない。 著者法コロイド滴走を應用してリグニンの新是 量法老確立する事が州來たので，乙の大要を報 击する。

\section{（II） 測定法の原理}

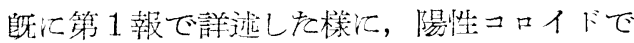
あるグリコールキトザン（G. Ch と略記）梳 ニロイドである L.S と化學量論的に結合す る。Cross Bevan の卓見によれば植物體中の リグニン洁之索監素化(以下 $\mathrm{Cl}$ 化之略記す)す

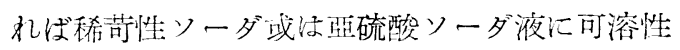
になる。とれはリグニンが $\mathrm{Cl}$ 化及び酸化作用 で分子中に解離性の原子團索生じその水溶性を 垌加する篇である。Cross and Bevan の全纎 維素の定量洼法この原理老隼用したものである。 從つてこの際の洗滌廢液中には，植物體中の! グニン注，㯺化リグニン（Cl.L と略記す）と して溶けている加けで法存く，正確には監化り グニンスルフォン酸（以下 Cl. L.S と略記す る）として溶けているわけである。故にての Cl. L.S を定量する事が出來れば植物體中のり 


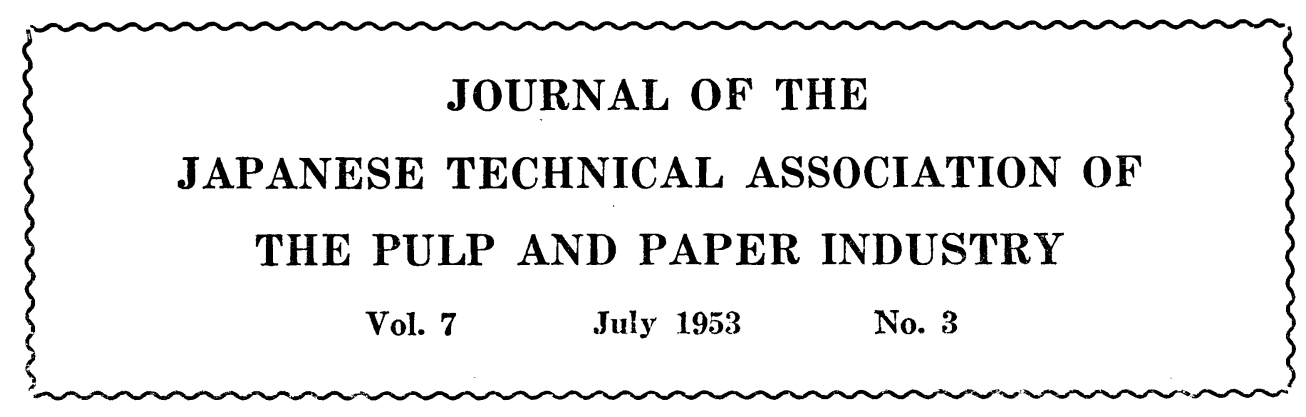

\title{
EINE NEUE BESTIMMUNGSMETHODE VON LIGNINSULFONSÄURE IN SULFITABLAUGE DURCH KOLLOIDTITRATION.
}

\author{
Ryoiti Senzyu, Isao Sakata und Kitsuji Nishida. \\ (Institut für Wiss̄enschaft und Industrie der Univ. Kyushu.)
}

Die bisherigen Forscher haben sich vergebens anstrengt, von verschiedenen aromatischen Aminen ein gutes Fällungsmittel zu entdecken. Diese Misserfolge kommen daher, dass die bisher geprüften Amine alles ausnahmsloss niedermolekulare Verbindungen sind. Solange man daher als Fällungsmittel für Ligninsulfonsäure das niedermolekulare Amin wie aromatisches Amin wählt, wird es, wie man auch sich bemüht, nicht gelingen, ein geeignetes Fällungsmittel $\mathrm{zu}$ entdecken. Von diesem Gesichtpunkt aus wählte ich als Fällungsmittel ein hochpolymeres Amin (Glykol-Chitosan), dessen Polymerizationsgrad etwa 600 war, und es ist mir gelungen, die Ligninsulonsäure in Ablauge bis auf bLigninsulfonsäure quantitativ (Empfindlichkeit über 4 Gamma) fällen zu lassen und sie titrimetrisch schnell und genau zu bestimmen. Das Prinzip dieser Kolloidtitration besteht darin, dass man eine bestimmte Menge der Glykol-Chitosan-lösung in Ablauge hinzufügt und das unverbrauchte Glykol-Chitosan mit polyvinylalkoholschwefelsäure Kalium (P.V.S.-K) gegen Toluidinblau zurücktitriert. Wenn man vorher das Aquivalentgewicht der Ligninsulfonsäure gegen Aminogruppe, das im allgemeinen bei üblichen Kochprozessen konstant (etwa 380) ist, weiss, so kann man gleich aus Polyaminverbrauch den Ligninsulfonsäuregehalt von Probelösung rechnen.

\section{EINE NEUE BESTIMMUNGSMETHODE DES LIGNINS DURCH KOLLOIDTITRATION}

\section{Ryoiti Senzyu, Motohiro Shimizu und Kitsuji Nishida.}

(Institut für Wissenschaft und Industrie der Univ Kyushu.)

In dem bei Gesamtcellulosebestimmung erhaltenen Waschabfall ist das Gesamtlignin der Probe als Chlorlignin (genauer gesprochen Chlorligninsulfonsäure) gelöst. Könnte man deshalb die Chlorligninsulfonsäure in der Lösung bestimmen, so wird es gelingen, die Cellulose und das Lignin von Probe gleichzeitig zu ermitteln. Diese Ziel wurde zum erstenmal von uns erreicht.

Nach Cross und Bevan löst man zuerst durch Wechselwirkung von Chlorgas und Natriumsulfit das Lignin von Probe vollständig heraus. Dazum ist es schon genug die zweimaligen Wechselwirkung von Chlorgas und Natriumsulfitlösung. Die so erhaltene Chlorligninsulfonsäure-Lösung wurde mit Ammoniak alkalisch gebracht und darauf auf 